\title{
Congenital Vertebral Synostosis Associated Range of Motion (ROM) and Visual Analog Scale(VAS)
}

\author{
Konjenital Vertebral Sinostozun Eklem Hareket Açıklığı (EHA) ve Görsel \\ Analog Skala (VAS) ile İlişkisi
}

\author{
Erdal Güngör ${ }^{1}$ Zeynep Karakuzu Güngör ${ }^{2}$ \\ ${ }^{1}$ Batman Training and Research Hospital Department of Orthopaedics and Traumatology, Batman,Turkey \\ ${ }^{2}$ Batman Training and Research Hospital Department of Phsycal Medicine and Rehabilitation, Batman,Turkey
}

\begin{abstract}
Objective: This study was determined the incidence of synostosis of vertebrae at various regions and to compare the increase in synostosis level with increased pain and decreased range of motion.

Methods: Seventy-eight adult vertebral columns were used to establish the incidence of congenital vertebral fusion in different spinal regions. The fusion was completed involving the bodies of the vertebrae without the vertebral arch.

Result: The incidence of congenital vertebral fusion was seen at the maximum in the cervical region $(61.53 \%)$, then in the lumbar $(21.79 \%)$ and thoracic regions $(16.66 \%)$ in decreasing order. Visual analog scale scores in the cervical region were seen as $4.9 \pm 1.3$, then in the lumbar and thoracic regions as $4.5 \pm 1.3$ and $2.3 \pm 1.4$, respectively. Congenital vertebral fusion in the cervical, thoracal, and lumbar region, respectively, was most common between $\mathrm{C} 2-\mathrm{C} 3$ and $\mathrm{C} 3-\mathrm{C} 4, \mathrm{~T} 10-\mathrm{T} 11$ and $\mathrm{T} 11-$ T12, and the L4-L5 intervertebral bodies. In the cervical region, statistically significant changes were observed between singlelevel fusion and 2 or more fusions in terms of movement and visual analog scale scores; however, in the thoracic and lumbar regions, no statistically significant difference was observed. There was a statistically significant change in the range of motion in the thoracic and lumbar regions, except in lumbar extension. No patient underwent surgery.

Conclusion: We found that the frequency of congenital vertebral fusion was most common in the cervical region. We observed that as the number of intervertebral congenital vertebral fusions increased in all cervical, thoracic and lumbar regions, the pain increased and the range of motion decreased. Congenital vertebral fusion causes resistant back pain and decreases the range of motion.
\end{abstract}

Key Words: clinical; congenital; synostosis; vertebrae

\section{Introduction}

The spinal column is the central structure in the human body that provides stability, movement, and posture. The vertebral column is divided into four regions: cervical, thoracic, lumbar, and pelvic (cranial to caudal order). The formation of the spine during embryogenesis is a highly regulated process. If the duration of spinal formation is disrupted, it can cause vertebral abnormalities

\begin{abstract}
Özet
Giriş: $\mathrm{Bu}$ çalışma, farklı seviyelerdeki vertebral füzyon insidansını belirlemek ve artmış vertebral füzyon ile ağrının artması ve azalmış eklem hareket açıklığını karşılaştırma amacıyla yapılmıştır.
\end{abstract}

Gereç ve Yöntem: Farklı spinal bölgelerde konjenital vertebral füzyon insidansını belirlemek için 78 yetişkin hasta ve vertebral ark füzyonu olmadan sadece vertebra gövde füzyonu olan hastalar çalışmaya dahil edildi.

Bulgular: Konjenital vertebral füzyon görülme sıklığ1 maksimum servikal bölgede ( $\%$ 61.53), daha sonra lomber $(\%$ $21.79)$ ve torasik bölgelerde (\% 16.66) görüldü. Servikal görsel analog skorları(VAS) $4.9 \pm 1.3$ sonra lomber, torasik bölgeler $4.5 \pm 1.3$ ve $2.3 \pm 1.4$ olarak görüldü. Servikal, torakal ve lomber bölgede konjenital vertebral füzyon en s1k C2-C3 ve C3C4, T10-T11 ve T11-T12 ile L4-L5 intervertebral gövdede görüldü. Servikal bölgede, hareket ve görsel analog skorları açısından tek seviyeli füzyon ile 2 veya daha fazla füzyon arasında istatistiksel olarak anlamlı değișiklikler gözlendi; ancak torasik ve lomber bölgelerde istatistiksel olarak anlamlı fark görülmedi.Lomber ekstansiyon haricinde torasik ve lomber bölgede eklem hareket açıklığında istatistiksel olarak anlamlı değişiklik saptand.

Sonuç: Konjenital vertebral füzyon en s1k servikal bölgede görüldü. Servikal, torakal ve lomber bölgelerde vertebral füzyon sayısı arttıkça ağrının arttığ1 görüldü. Konjenital vertebral füzyon, dirençli sırt ağrısına neden olduğu ve eklem hareket açıklığında azalmaya yol açtığı gözlemlendi.

Anahtar Kelimeler: klinik; konjenital; sinostoz; vertebra

such as transitional vertebrae, block vertebrae, butterfly vertebrae, hemivertebrae, and in extreme cases, spina bifida. (1). The synostosis of vertebrae can be congenital or acquired (2). Acquired synostosis of the vertebrae can be secondary to tuberculosis, vertebral fusion surgery, juvenile rheumatoid arthritis, trauma, or other infections (3). Fusion of the two vertebrae is called spondylosynthesis after surgery (2). Congenital

* Sorumlu Yazar: Erdal Güngör Gültepe, Eflatun Cd. No:1, 72070 Batman Merkez/Batman Tel: (0488) 2213066 E-mail: egungor_49@hotmail.com Orcid:Erdal Güngör 0000-0002-9556-2166, Zeynep Karakuzu Güngör 0000-0002-9010-334X Geliş Tarihi:24.01.2021 Kabul Tarihi:13.09.2021 
synostosis of the vertebrae is most common in the cervical region, but can also be seen in the thoracic and lumbar regions. (4,5). Congenital anterior synostosis of vertebrae is usually asymptomatic (6). Block vertebrae may be associated with neurological deficits and cause limited range of motion and early degenerative changes in the spine $(5,7)$. The aim of this study was to compare the incidence of cervical thoracic and lumbar vertebral regions in patients with congenital vertebral fusion and to assess pain and range of motion (ROM) according to fusion regions. it was also aimed to compare the increase in fusion level with increased pain and decreased ROM.

Table 1: Patient Demographics for Each Group.

\begin{tabular}{lllll}
\hline & $\begin{array}{l}\text { Cervical } \\
(\mathrm{n}=48)\end{array}$ & $\begin{array}{l}\text { Thoracic } \\
(\mathrm{n}=13)\end{array}$ & $\begin{array}{l}\text { Lumbar } \\
(\mathrm{n}=17)\end{array}$ & $\mathrm{p}$ \\
\hline $\begin{array}{l}\text { Age }(\operatorname{mean} \pm \mathrm{SD}) \\
\text { Sex }(\mathrm{n}, \%)\end{array}$ & $56.1 \pm 12.0$ & $58.1 \pm 9.6$ & $54.4 \pm 12.6$ & 0.714 \\
Male & $20(41.7)$ & $4(30.8)$ & $6(35.3)$ & \\
Female & $28(58.3)$ & $9(69.2)$ & $11(64.7)$ & 0.739 \\
\hline
\end{tabular}

Table 2: Fusion Levels for Each Group

\begin{tabular}{lllll}
\hline & $\begin{array}{l}\text { Cervical } \\
(\mathrm{n}=48)\end{array}$ & $\begin{array}{l}\text { Thoracic } \\
(\mathrm{n}=13)\end{array}$ & $\begin{array}{l}\text { Lumbar } \\
(\mathrm{n}=17)\end{array}$ & $\mathrm{p}$ \\
\hline Fusion Level $(\mathrm{n}, \%)$ & $43(89.6)$ & $10(76.9)$ & $14(82.4)$ & 0.521 \\
Single & $5(10.4)$ & $3(23.1)$ & $3(17.6)$ & \\
Multiple & $4.9 \pm 1.3$ & $2.3 \pm 1.4$ & $4.5 \pm 1.3$ & $0.0082^{\mathrm{a}, \mathrm{c}}$ \\
\hline VAS (mean \pm SD) &
\end{tabular}

a: Cervical vs. Thoracic; b: Cervical vs. Lumbar; c: Thoracic vs. Lumbar

\section{Materials and Methods}

78 patients diagnosed with vertebral body fusion were included in the study from patients admitted to the study between 2020 and 2021. Patients between the ages of 18-80 with vertebral body fusion and evaluated in the outpatient clinic were included in the study. The fusion was completed involving the bodies of the vertebrae without the vertebral arch. The vertebrae of all the regions were studied to see if there is any abnormal fusion between contiguous vertebral bodies. The study was managed following the principles of the Declaration of Helsinki. Ethics committee approval was obtained from the Ministry of Health University Ethic committee (Ethic committee no: 263/24.02.2021). The cervical, thoracic or lumbar range of motion of patients was measured with a goniometer and visual analog scale (VAS) scores were recorded in patients with congenital vertebral fusion. The vertebrae of all the regions were inspected to find if there exists any abnormal fusion between adjacent vertebral bodies, pedicles, laminae, spines or transverse processes using computer tomography (CT), magnetic resonance imaging (MRI), and X-rays in all patients. Patients whose vertebrae were fractured or fused secondary to any disease (infection, vertebrae surgery, a history of inflammatory arthritis, trauma, malignancy, tuberculosis), severe deformities, or systemic diseases were excluded from the study. Patients with all intact adult dry congenital vertebrae fusion, who were aged 18-80 years, were included in the study.

Statistic: Data analysis was performed using the SPSS Ver. 22 package program. The ShapiroWilk test was used to test the normality of the distribution of numeric variables. Mean and standard deviation were used to described numeric variables, and categorical variables were described as frequency and percentage. More than two independent means were compared using that Kruskal-Wallis test, followed by the posthoc Dunn's test. In cases where the degree of freedom 
was not sufficient, the Mann-Whitney U test was used to compare the pairs and Bonferroni correction was applied. Two independent means were compared using the Mann-Whitney U test. The relationship between two categorical variables was investigated using the Chi-square test. The

Table 3: Frequency of Fusion Levels for Each Group

\begin{tabular}{|c|c|c|c|c|c|}
\hline \multicolumn{2}{|c|}{ Cervical $(n=48)$} & \multicolumn{2}{|c|}{ Thoracic $(n=13)$} & \multicolumn{2}{|c|}{ Lumbar $(n=17)$} \\
\hline Region & $\begin{array}{l}\text { Frequency } \\
(\mathrm{n}, \%)\end{array}$ & Region & $\begin{array}{l}\text { Frequency } \\
(\mathrm{n}, \%)\end{array}$ & Region & $\begin{array}{l}\text { Frequency } \\
(\mathrm{n}, \%)\end{array}$ \\
\hline $\mathrm{C} 1-\mathrm{C} 2$ & $0(0)$ & T1-T2 & $2(15.4)$ & L1-L2 & $4(23.5)$ \\
\hline C2-C3 & $15(31.3)$ & T2-T3 & $3(23.1)$ & L2-L3 & $3(17.6)$ \\
\hline C3-C4 & $16(33.3)$ & T3-T4 & $0(0)$ & L3-L4 & $2(11.8)$ \\
\hline C4-C5 & $8(16.7)$ & T4-T5 & $0(0)$ & L4-L5 & $9(52.9)$ \\
\hline C5-C6 & $13(27.1)$ & T5-T6 & $1(7.7)$ & L5-S1 & $4(23.5)$ \\
\hline C6-C7 & $7(14.6)$ & T6-T7 & $0(0)$ & & \\
\hline \multirow[t]{6}{*}{ C7-T1 } & $1(2.1)$ & T7-T8 & $0(0)$ & & \\
\hline & & T8-T9 & $0(0)$ & & \\
\hline & & Т9-Т10 & $1(7.7)$ & & \\
\hline & & T10-T11 & $4(30.8)$ & & \\
\hline & & T11-T12 & $4(30.8)$ & & \\
\hline & & T12-L1 & $2(15.4)$ & & \\
\hline
\end{tabular}

Table 4: The relationship between fusion level and other variables in patients with cervical region

\begin{tabular}{|c|c|c|c|c|}
\hline & & Fusion Le & & \\
\hline & $\begin{array}{l}\text { Total } \\
(n=48)\end{array}$ & $\begin{array}{l}\text { Single } \\
(n=43)\end{array}$ & $\begin{array}{l}\text { Multiple } \\
(n=5)\end{array}$ & $\mathrm{p}$ \\
\hline Age (mean \pm SD) & $56.1 \pm 12.0$ & $56.3 \pm 12.2$ & $54.2 \pm 12.0$ & 0.577 \\
\hline $\operatorname{Sex}(n, \%)$ & & & & \\
\hline Male & $20(41.7)$ & $16(37.2)$ & $4(80)$ & \\
\hline Female & $28(58.3)$ & $27(62.8)$ & $1(20)$ & 0.088 \\
\hline Flexion (mean \pm SD) & $45.1 \pm 3.2$ & $45.6 \pm 2.8$ & $41.0 \pm 3.8$ & 0.008 \\
\hline Extension $($ mean \pm SD) & $54.2 \pm 3.1$ & $54.6 \pm 2.9$ & $50.0 \pm 1.4$ & 0.002 \\
\hline Right lateral flex (mean $\pm S D)$ & $40.3 \pm 3.1$ & $40.7 \pm 2.9$ & $36.4 \pm 2.6$ & 0.012 \\
\hline $\begin{array}{l}\text { Left lateral flex } \\
(\text { mean } \pm S D)\end{array}$ & $40.3 \pm 3.1$ & $40.7 \pm 2.9$ & $36.4 \pm 2.6$ & 0.012 \\
\hline Right rotation (mean $\pm \mathrm{SD})$ & $63.9 \pm 3.4$ & $64.2 \pm 3.2$ & $61.4 \pm 4.3$ & 0.184 \\
\hline Left rotation (mean $\pm \mathrm{SD})$ & $63.9 \pm 3.4$ & $64.2 \pm 3.3$ & $61.4 \pm 4.2$ & 0.184 \\
\hline VAS (mean $\pm S D)$ & $4.9 \pm 1.3$ & $4.7 \pm 1.2$ & $6.6 \pm 0.5$ & 0.001 \\
\hline
\end{tabular}

study was performed at a 95\% confidence level ( $p$ $<0.05$ was considered statistically significant).

\section{Results}

Seventy-eight patients were included in the study, $38.4 \%(n=30)$ were male and $61.5 \%(n=48)$ were female. The mean age was $56.1 \pm 12.0$ years in patients with cervical involvement, 58.1 \pm 9.6 years in patients with thoracal involvement and $54.4 \pm 12.6$ years in patients with lumbar involvement. There was no significant difference between the mean ages of the three groups ( $p=$
0.714), and there was no difference between the three groups in terms of sex distribution ( $\mathrm{p}=$ 0.739). The demographics of the patients are shown in Table 1. All patients gave VAS pain scores, and pain other than fusion-related was excluded. The mean VAS was $4.9 \pm 1.3$ in patients with cervical involvement, $2.3 \pm 1.4$ in patients with thoracal involvement, and $4.5 \pm 1.3$ in patients with lumbar involvement. There was a statistically significant difference between the mean VAS scores of the three groups $(\mathrm{p}=0.0082)$. This difference was due to the fact that the mean VAS score of patients with thoracic involvement 
was significantly lower than that of patients with cervical and lumbar involvement. Single-level or multi-level fusions and VAS scores of patients are shown in Table 2. Table 3 shows the frequency of fusion levels of the three regions. The most common fusion in the cervical region was C2-C3 and C3-C4, T10-T11 and T11-T12 in the thoracic region, and L4-L5 in the lumbar region. As shown in Table 4, there was a significant difference between single-level fusion and multi-level fusion in terms of flexion, extension, right lateral flexion, and left lateral flexion in patients with cervical fusion. As shown in Table 5, there was a significant difference between single-level fusion and multi-level fusion in terms of flexion, extension, and Right-Left rotation in patients with thoracic fusion. As shown in Table 6, there was a significant difference between single-level fusion and multi-level fusion in terms of flexion and Right-Left rotation in patients with lumbar fusion.

Table 5: The relationship between fusion level and other variables in patients with thoracic region fusion

\begin{tabular}{|c|c|c|c|c|}
\hline & & Fusion L & & \\
\hline & $\begin{array}{l}\text { Total } \\
(n=13)\end{array}$ & $\begin{array}{l}\text { Single } \\
(n=10)\end{array}$ & $\begin{array}{l}\text { Multiple } \\
(n=3)\end{array}$ & $\mathrm{p}$ \\
\hline Age $($ Mean \pm SD $)$ & $58.1 \pm 9.6$ & $58.0 \pm 9.3$ & $58.3 \pm 12.6$ & 0.866 \\
\hline $\operatorname{Sex}(n, \%)$ & & & & \\
\hline Male & $4(30.8)$ & $3(30)$ & $1(33.3)$ & \\
\hline Female & $9(69.2)$ & $7(70)$ & $2(66.7)$ & 0.706 \\
\hline Flexion (mean $\pm \mathrm{SD})$ & $44.9 \pm 3.2$ & $46.2 \pm 2.3$ & $40.3 \pm 0.6$ & 0.011 \\
\hline Extension (mean $\pm \mathrm{SD})$ & $43.3 \pm 2.4$ & $44.2 \pm 1.6$ & $40.3 \pm 2.1$ & 0.026 \\
\hline $\mathrm{R}-\mathrm{L}$ rotation $($ mean $\pm \mathrm{SD})$ & $24.2 \pm 2.5$ & $25.4 \pm 1.2$ & $20.3 \pm 1.5$ & 0.010 \\
\hline VAS (mean $\pm S D)$ & $2.3 \pm 1.4$ & $2.6 \pm 1.3$ & $2.9 \pm 1.5$ & 0.194 \\
\hline
\end{tabular}

Table 6: The relationship between fusion level and other variables in patients with lumbar region fusion

\begin{tabular}{|c|c|c|c|c|}
\hline & & Fusion Le & & \\
\hline & $\begin{array}{l}\text { Total } \\
(n=17)\end{array}$ & $\begin{array}{l}\text { Single } \\
(n=14)\end{array}$ & $\begin{array}{l}\text { Multiple } \\
(\mathrm{n}=3)\end{array}$ & $\mathrm{p}$ \\
\hline Age (mean \pm SD) & $54.4 \pm 12.6$ & $54.2 \pm 13.5$ & $55.3 \pm 9.1$ & 0.800 \\
\hline $\operatorname{Sex}(n, \%)$ & & & & \\
\hline Male & $6(35.3)$ & $4(28.6)$ & $2(66.7)$ & \\
\hline Female & $11(64.7)$ & $10(71.4)$ & $1(33.3)$ & 0.272 \\
\hline Flexion (mean \pm SD) & $52.8 \pm 4.4$ & $53.9 \pm 4.0$ & $47.7 \pm 2.5$ & 0.019 \\
\hline Extension (mean \pm SD) & $21.9 \pm 2.1$ & $22.2 \pm 2.1$ & $20.3 \pm 0.6$ & 0.158 \\
\hline Right lateral flex (mean $\pm S D)$ & $20.9 \pm 2.8$ & $21.8 \pm 2.1$ & $16.7 \pm 0.6$ & 0.007 \\
\hline Left lateral flex (mean \pm SD) & $20.9 \pm 2.8$ & $21.8 \pm 2.1$ & $16.7 \pm 0.6$ & 0.007 \\
\hline VAS $($ mean $\pm S D)$ & $4.5 \pm 1.3$ & $4.2 \pm 1.1$ & $5.7 \pm 1.5$ & 0.105 \\
\hline
\end{tabular}

\section{Discussion}

Some studies have been done to investigate the frequency of spinal anomalies. Early detection of vertebral synostosis in the cervical, thoracic and lumbar regions may indicate the presence of congenital defects (2). Acquired vertebral fusion and congenital vertebral fusion can be distinguished by $\mathrm{x}$ ray imaging or MR imaging (8). In contrast, congenital fusions are characterized by the absence of intervertebral discs or their replacement by a radio- opaque line (9). The fusion was completed involving the bodies of the vertebrae without the vertebral arch was seen in the present study. According to the previous study result, the prevalence of vertebral fusion in a Lithuanian population was $2.6 \%$ in the cervical, $1.65 \%$ in the thoracic, and $0.5 \%$ in the lumbar spine (2). Frequency of congenital vertebral fusion was most common in the cervical region, especially between the C2-C4 vertebrae, and then in the lumbar and thoracic vertebrae, respectively was found in our study. Congenital cervical vertebral 
fusion causes a decreased length of the spine, webbed neck, low posterior hairline, and signs of peripheral nerve compression. Previously, the incidence of C2C3 fusion was found as $0.4-0.7 \%$ (5). Similarly, the most common fusion in the cervical region was $\mathrm{C} 2$ C3 and C3-C4 in our study. Abnormal segmentation of sclerotomes leading to the formation of block vertebra during development may be caused by a decreased blood supply during the 3rd - 8th weeks of intrauterine life (10). Farman and Escobar reported that radiographic images of vertebral bodies with congenital anomalies can be caused by atlas, odontoid and atlas deformity, spina bifida, and abnormal ossification defects in fusion or normal segmentation occipitalization. There is a higher incidence of osteophyte formation at levels attached to fusion in patients with cervical synostosis (5). Surgical treatment of the block vertebra has a higher risk of morbidity and mortality. Cervical synostosis usually occurs due to trauma, degenerative and inflammatory dislocations of the upper and lower cervical spine (11). Butler explained the anterior bony fusion of two vertebral bodies to be a rare manifestation of Scheuermann's vertebral osteochondritis, a condition of herniation of intervertebral disc tissues through the cartilage endplate of the vertebral bodies, which later on ossifies resulting in fusion of vertebral bodies (12). Although there was vertebral body fusion, no clinical association was observed with a congenital disease in the present study. In Kubavat's study, sacralization of the fifth lumbar vertebra was present in 21 (11.1\%) cases and lumbarization of the first sacral vertebra in $3(1.3 \%)$ cases. The author speculated that these anomalies could be a cause of low back pain, in females, leading to difficult labor (13). Similarly, range of motion of spine was observed restriction in all our patients. All of patients had low back pain. VAS score was observed high in cervical region involvement than the other region. Previous studies concluded that any change from the normal pattern of lumbar and sacral vertebrae such as lumbosacral transitional vertebra resulted from the mutation of Hox-10 and Hox-11 genes $(14,15)$. Sharma et al. concluded that after the lumbosacral region, the cervical vertebrae were most commonly involved in congenital fusion, especially those of the upper cervical spine. In contrast, thoracic and lumbar vertebrae were usually fused due to acquired causes, which may be infective, traumatic, or surgical, and vertebral synostosis could be a helpful feature for identification (16). The incidence of congenital vertebral fusion was seen at the maximum in the cervical region $(61.53 \%)$, then in the lumbar $(21.79 \%)$ and thoracic regions $(16.66 \%)$ in decreasing order in the present study.The intervertebral discs form one-fifth of the vertebral column (17). The absence of intervertebral discs causes subsequent shortening of the trunk. Synostosis of the vertebrae can narrow the rib cage, causing some rib cage deformities and respiratory distress (18, 19). Congenital block vertebrae can be accompanied by many clinical conditions, including abnormal spinal curvatures (e.g. scoliosis), Sprengel's deformity, respiratory problems, hemivertebrae, cleft palate, the anomaly of the kidney, cardiac abnormalities 20, 21). None of the above anomalies were observed in our patients.

Limitation of this study: The limitations of this study were that the number of cases was low and that pain could be caused by reflected pains or nerve root compression, and that limited ROM could be caused by that pain.

\section{Conclusion}

In this study, we found that the frequency of congenital vertebral fusion was most common in the cervical region, especially between the C2-C4 vertebrae, and then in the lumbar and thoracic vertebrae, respectively. We observed that as the number of intervertebral congenital vertebral fusions increased in all three regions, the pain increased and ROM decreased. Congenital vertebral fusion causes resistant back pain and decreases ROM.

Conflict of interests: There is no conflict of interest for the study

Financial disclosure statement: There is no financial disclosure statement for the study.

Author Contributions: All authors contributed equally.

\section{Referance}

1. Ruiter CD. Congenital vertebral defects. Embryo Project Encyclopaedia 2010.

2. Kulkarni V, Ramesh BR. A spectrum of vertebral synostosis. Int J Basic Appl Med Sci 2012; 2(2): 71-77.

3. Erdil H, Yildiz N, Cimen M. Congenital fusion of cervical vertebrae and its clinical significance. J Anat Soc India 2003; 52(2): 125127.

4. Seaver LH, Boyd E. Spondylocarpotarsal synostosis syndrome and cervical instability. Am J Med Genet 2000; 91(5): 340- 344.

5. Soni P, Sharma V, Sengupta J. Cervical vertebral anomalies-incidental findings on lateral cephalograms. Angle Orthod 2008; 78(1): 176-180. 
6. Korey A, Iltekin D, Serdar K, Yasin D. Congenital anterior fusion of the lumbar vertebrae misdiagnosed as spondyloarthritis;a casereport.m/esprm2012/esprm2012.02f00c1. Accessed on: May 15, 2013.

7. Shankar VV, Roopa RK. Block vertebra, Fusion of axis with the third cervical vertebraa case report. Int J Anat Var 2011; 4: 15-16.

8. Meschan I. Analysis of roentgen signs in general radiology. Vol. 1. WB Saunders Company, Philadelphia, London. 618-620.

9. Brown MW, Templeton AW, Hodges FJ 3rd. The incidence of acquired and congenital fusion in the cervical spine. Am J Roentgenol Radium Ther Nucl Med 1964; 92: 1255-1259.

10. Wazir S, Mahajan A. Fusion of axis with third cervical vertebra- a case report. Indian J Fundamental Appl Life Sci 2011;1(4):164-166

11. Sherekar SK, Yadav YR, Basoor AS, Baghel A, Adam N. Clinical implications of alignment of upper and lower cervical spine. Neurol India 2006; 54(3): 264-267.

12. Butler RW. Spontaneous anterior fusion of vertebral bodies. J Bone Joint Surg $\mathrm{Br}$ 1971;53(2):230-235.

13. Dharati K, Nagar SK, Ojaswini M, Dipali T, Paras S, Sucheta P. A study of sacralisation of fifth lumbar Vertebra in Gujarat. National J Med Res 2012; 2(2): 211-213.
14. Carapuco M, Novoa A, Bobola N, Mallo M. Hox genes specify vertebral types in the presomitic mesoderm. Genes Dev 2005; 19(18): 2116-2121.

15. Wellik DM, Capeechi MR. Hox 10 and Hox 11 genes are required to globally pattern the mammalian skeleton. Science 2003;301(5631):363-367.

16. Sharma M, Baidwan S, Jindal AK, Gorea RK. A study of vertebral synostosis and its clinical significance. J Punjab Acad Forensic Med Toxicol 2013;13(1):20-24.

17. Standring S. The Back. In Gray's AnatomyThe anatomical basis of clinical practice. 40th edition, Churchil Livingstone Elsevier, Spain, 2008: 719-720.

18. Bhargava S. Radiological Differential Diagnosis. 1st edition, Jaypee Brothers New Delhi, 2005: 528.

19. Thomas D, Kulkarni BG. A case of fusion of thoracic vertebra. Journal of Ayurveda and Holistic Medicine 2013; 1(5): 23-26.

20. Fernandes T, Costa C. Klippel-Feil syndrome with other associated anomalies in a medieval Portugese skeleton (13th -15 th century). J Anat 2007; 211(5):681-685.

21. Batra S, Ahuja S. Congenital Scoliosis: management and future directions. Acta Orthop Belg 2008; 74(2): 147-160. 